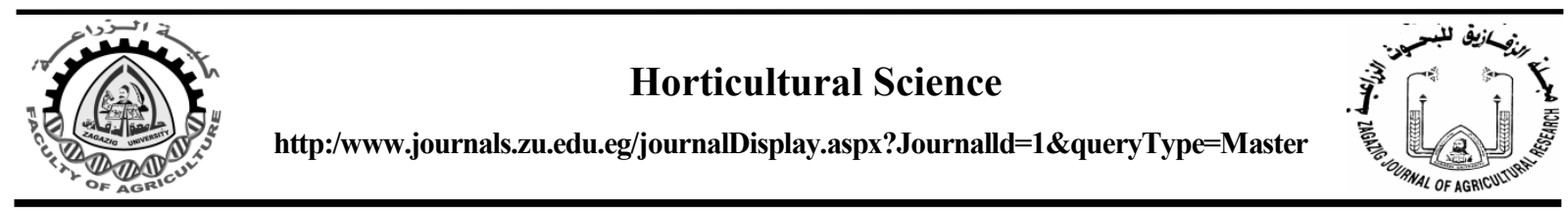

\title{
EVALUATION OF SOME FACTORS AFFECTING IN VITRO MICROPROPAGATION OF FEW SEEDED FRUIT GUAVA TREES
}

\author{
Doaa S. Mahmoud*, G.F. Sourial, Atteyat S. Abd El-Aziz and R.A. Al-Ashkar
}

Hort. Dept., Fac. Agric., Zagazig Univ., Egypt

Received: 16/3/2017 ; Accepted: 05/04/2017

\begin{abstract}
This study was carried out during the period from 2013 to 2016 in the Plant Tissue Culture Laboratory Hort. Dept., Fac. Agric., Zagazig University, Egypt to create a protocol for propagating few seeded fruit guava trees throughout the various stages of tissue culture technique. During the establishment stage, explants (nodal explants and shoot tips) were excised from 6- monthold seedlings grown in the green house. The excised explants were cultured in Murashige and Skoog (MS) medium supplemented with $1 \mathrm{mg} / 1$ benzyl adenine (BA) combined with $100 \mathrm{mg} / \mathrm{l}$ polyvinylpyrrelidone (PVP). Results showed that nodal explants proved to be better than shoot tips concerning growth parameters. Different BA concentrations i.e. $0.0,0.5,1$ or $2 \mathrm{mg} / 1$ proved the efficiency of $2 \mathrm{mg} / 1 \mathrm{BA}$ for shoot proliferation from nodal explants, followed by $1 \mathrm{mg} / \mathrm{l} \mathrm{BA}$. Inoculation nodal explants during different dates revealed that spring season (mid April) produced the best growth parameters. Obtained shoots about $1 \mathrm{~cm}$ length from establishment stage were cultured in MS medium provided with BA or kinetin (Kin.), at different concentrations $(0.0,0.5,1,2,4$, or $6 \mathrm{mg} / \mathrm{l})$. Results showed that BA recorded the highest multiplication rate compared with Kin., which produced one shoot, only, whereas $2 \mathrm{mg} / \mathrm{l} \mathrm{BA}$ gave the highest number of shoots/ explant (10.62 shoots/ explant). Addition of sucrose at 20,30 or $40 \mathrm{~g} / 1$ to MS medium supported with $2 \mathrm{mg} / 1 \mathrm{BA}$ enhanced the efficiency of $40 \mathrm{~g} / 1$ sucrose concerning number of shoots/explant (12 shoots/explant). The combination of $2 \mathrm{mg} / 1 \mathrm{BA}$ and different auxins (NAA, IAA or IBA) at low concentrations showed that $2 \mathrm{mg} / 1 \mathrm{BA}$ combined with $0.5 \mathrm{mg} / 1 \mathrm{IBA}$ gave the highest number of shoots/ explant (11.20 shoots/ explant). During rooting stage, using each of NAA, IBA or IAA at $0,1,2$ or $4 \mathrm{mg} / \mathrm{l}$ in MS medium, resulted in shoot rooting. Although NAA resulted in more number of roots/ shoot, IBA at 1 or $2 \mathrm{mg} / \mathrm{l}$ was adequate for producing better rooting shoots for acclimatization stage. The obtained rooted plantlets could be successfully acclimatized in peat moss medium incorporated with sand at 1:2(V/V), since it gave $100 \%$ survival.
\end{abstract}

Key words: Micropropagation, in vitro culture, few seeded fruit guava trees, nodal explants, shoot tips, benzyl adenine (BA), kinetin (Kin.), sucrose, auxins, IBA.

\section{INTRODUCTION}

Guava, (Psidium juagava L.), belongs to the family Myrtaceae. The origin of guava is tropical America from Mexico to Piro. Guava is a popular fruit crop, cultivated in many countries such as USA, Brazil, Colombia, India, Egypt, South Africa, and Saudi Arabia due to its favorite taste and high fruit vitam. C content. Guava includes tree strain-types as follows:

\footnotetext{
* Corresponding author: Tel. : +201001998319

E-mail address: doa_sabry92@yahoo.com
}

\section{Seeded Strains (Balady)}

Fruit set of these strains occurs simultaneously through self and cross pollinations. Balady strains are containing large numbers of seeds. Vegetative and fruiting traits show clear segregation due to the heterozygous genotype. Balady strains bear, usually, heavy crops, but their main defect is the high fruit seed content. Also, the seedling trees have different responses to the environmental factors and required different horticultural practices. 


\section{Strains with Few Seeds in Fruits}

North Egypt zone regions have guava strains with fewer number of seeds and have local names like: Rashidi, Baraka,... etc. Flower bagging, to insure self pollination, is usually used to obtain true to type plants by seed propagation.

\section{Seedless Guava: (Banaty)}

Fruit set of seedless guava is parthenocarpic. Fruits are relatively large and lower sweeter, but the trees usually bear lower yields compared to other guava strains, particularly seeded ones.

Plant growth regulators are numerous chemical substances that profoundly influence the growth and differentiation of plant cells, tissues and organs. Auxins stimulate division and elongation of cell. On the other hand, cytokinins are able to stimulate cell division and induce shoot bud formation in tissue culture.

Mishra et al. (2007) mentioned that culturing nodal segments of guava cv. Pant Prabhatin in MS media containing $4.0 \mathrm{mg} / 1 \mathrm{BA}$ and $0.2 \mathrm{mg} / 1$ IBA resulted in higher shoot proliferation. Also, Usman et al. (2012) worked on micropropagation of Elite guava (Psidium guajava L.) strains of cv. Safeda, found that enhancing sucrose supplement to $45 \mathrm{~g} / 1$ improved plant growth and development of shoot and root length as well as leaf area compared to $30 \mathrm{~g} / 1$ of sucrose in the media. Likewise, Rabeh et al. (2015) performed a study on micropropagation of guava cvs. Banaty, Sabahy and Mobaker, and mentioned that $\mathrm{BA}$ at $1.0 \mathrm{mg} / \mathrm{l}$ gained the best effect on shoot production per explant of the three guava cultivars.

The main goal of this study was evaluating the effect of some treatments affecting micropropagation of few seeded fruit guava trees to achieve guava plantations of the same origin.

\section{MATERIALS AND METHODS}

This study was carried out in the Plant Tissue Culture Laboratory, Horticulture Department, Faculty of Agriculture, Zagazig University, Egypt throughout the period from 2013 to 2016.
The used basal medium was Murashige and Skoog (MS) (1962). The considered medium was supplemented with the other tested additions according to the aim of each experiment. $\mathrm{pH}$ medium was adjusted to 5.8 . Afterwards, $50 \mathrm{ml}$ of the medium was poured into $370 \mathrm{ml}$ jars, which were immediately plugged with polypropylene closures. The medium was then autoclaved at $121^{\circ} \mathrm{C}$ and 1.1 $\mathrm{kg} / \mathrm{cm}^{2}$ pressure for 20 minutes. All cultures of the different experiments were maintained in a growth room chamber at $25 \pm 2^{\circ} \mathrm{C}$ and exposed to $16 \mathrm{hr}$., day photoperiod and $8 \mathrm{hr}$., darkness at an intensity of 2000 Lux from cool white fluorescent lamps.

\section{Establishment Stage}

Effect of explant type on micropropagation during establishment stage of few seeded fruit guava trees

Shoot tips (with two lateral buds) and nodal explants of about $1 \mathrm{~cm}$ length and $2-3 \mathrm{~mm}$ thickness were obtained from sprouted shoots of 6 months old seedlings grown in the green house. The explants were soaked in a soap solution for $5 \mathrm{~min}$., then washed under running water for $1 \mathrm{hr}$. The explants were then soaked in rhizolex fungicide solution $(2 \mathrm{~g} / \mathrm{l})$ for $30 \mathrm{~min}$., followed by washing with distilled water three times then transferred to aseptic conditions inside the culture cabinet (laminar air flow cabinet), and then sterilized with the mercuric chloride at $0.1 \%$ for $3 \mathrm{~min}$., followed by rinsing explants three times with sterilized distilled water, then soaked in Clorox solution $(\mathrm{NaOCl}$, $5.25 \%$ free chlorine) at $5 \%$ for $5 \mathrm{~min}$., followed by rinsing explants three times with sterilized distilled water under the same conditions. The sterilized explants were cultured in glass jars $(100 \mathrm{ml})$ containing MS medium amended with $1 \mathrm{mg} / 1$ benzyl adenine (BA). In establishment stage experiments, the medium was amended with $100 \mathrm{mg} / 1$ polyvinylpyrrelidone (PVP) to prevent browning.

\section{Effect of some benzyl adenine (BA) concentrations during establishment stage on nodal explants of few seeded fruit guava trees}

The sterilized nodal explants were cultured on MS medium supplemented with different concentrations of BA $(0.0,0.5,1$, or $2 \mathrm{mg} / \mathrm{l})$. 
Effect of nodal explant inoculation date during establishment stage of few seeded fruit guava trees

Nodal explants were inoculated during spring (mid-April), summer (mid-July), autumn (mid-October), and the winter seasons (midJanuary) then sterilized as previously mentioned and cultured on MS medium supplemented with $1 \mathrm{mg} / 1 \mathrm{BA}$.

The data recorded for all experiments of establishment stage after six weeks of culture period were: 1 . Survival percentage; 2 . Number of shoots/explant; 3 . Shoot length; 4 . Number of leaves/shoot and 5. Other observations.

\section{Multiplication stage}

In this stage $1 \mathrm{~cm}$ length growing shoots, previously obtained from nodal explants cultured on MS medium with $1 \mathrm{mg} / \mathrm{l} \mathrm{BA}$, were used in the following experiments of multiplication stage :

Effect of benzyl adenine (BA) concentration during multiplication stage of few seeded fruit guava trees

$1 \mathrm{~cm}$ length growing shoots previously obtained from nodal explants, were cultured on MS medium supplemented with different concentrations of BA $(0.0,0.5,1,2,4$, or 6 $\mathrm{mg} / 1)$.

Effect of kinetin (Kin.) concentration during multiplication stage of few seeded fruit guava trees

$1 \mathrm{~cm}$ length growing shoots previously obtained from nodal explants, were cultured on MS medium provided with different concentrations of Kin. $(0.0,0.5,1,2,4$, or $6 \mathrm{mg} / 1)$.

Effect of sucrose concentration in MS medium during multiplication stage of few seeded fruit guava trees

$1 \mathrm{~cm}$ length growing shoots previously obtained from nodal explants, were cultured on MS medium amended with $2 \mathrm{mg} / \mathrm{l} \mathrm{BA}$ and different concentrations of sucrose $(20,30$, or $40 \mathrm{~g} / \mathrm{l})$.

Effect of BA and auxins during multiplication stage of few seeded fruit guava trees

$1 \mathrm{~cm}$ length growing shoots previously obtained from nodal explants, were cultured on
MS medium supplemented with $2 \mathrm{mg} / \mathrm{l} \mathrm{BA}$ alone or combined with 0.5 or $1 \mathrm{mg} / 1$ of $\alpha$ - naphthalene acetic acid (NAA), indol-3- acetic acid (IAA), or indole -3-butyric acid (IBA).

Number of shoots/explant, average shoot length $(\mathrm{cm})$, average number of leaves/shoot and other observations were determined six weeks later of culture period.

\section{Rooting Stage}

\section{Effect of different auxins on rooting stage of few seeded fruit guava trees}

$1.5 \mathrm{~cm}$ length growing shoots which were previously obtained from multiplication stage, were cultured on MS medium supplemented with $0.0,0.5,1,2$ or $4 \mathrm{mg} / 1$ of $\alpha$ - naphthalene acetic acid (NAA), indol-3- acetic acid (IAA), or indole -3- butyric acid (IBA) beside control (without growth regulators).

Rooting percentage, number of roots/shoot, total length $(\mathrm{cm})$ of roots/shoot, shoot length $(\mathrm{cm})$, number of leaves/shoot and other observations were determined six weeks later of culture period.

\section{Acclimatization stage}

The objective of this stage was to adapt the plantlets, obtained in vitro before transferring to the open field. The produced plantlets were washed with tap water, and then disinfected by immersing the roots in rhizolex solution $(1.0 \mathrm{~g} / \mathrm{l})$ for 10 minutes. The plantlets were then transferred to plastic pots $(9 \times 7 \mathrm{~cm})$ containing: sand + peat moss at $1: 1,2: 1$ and $3: 1(V / V)$, or Peat moss alone. The cultured pots were covered with polyethylene bags to keep high relative humidity around the plantlets during incubation at $25 \pm 2{ }^{\circ} \mathrm{C}$ and 2000 Lux photoperiod in a growth room. Survival percentage; plantlet length $(\mathrm{cm})$; and number of leaves / shoot were determined six weeks later of acclimatization stage.

\section{Statistical Analysis}

The statistical layout of all the above mentioned experiments during the whole work was the complete randomized design. The obtained data were statistically analyzed according to Snedecor and Cochran (1980). The means were compared using the Duncan's (1955) multiple range test at 0.05 . 
934

\section{RESULTS AND DISCUSSION}

\section{Establishment Stage}

Effect of explant type on some
micropropagation parameters during
establishment stage of few seeded fruit
guava trees

Results in Table 1 and Photo 1 show that survival percentage was $100 \%$ in shoot tips and nodal explants. The highest number of shoots/ explant (6.17 shoots/explant), the longest shoot $(2.30 \mathrm{~cm})$, and the highest number of leaves/ shoot (10.09 leaves/shoot) were produced by nodal explants with significant differences against values of shoot tips explant $(2.67,1.16$ and 7.36, respectively).

Effect of benzyl adenine (BA) concentration on some growth parameters of nodal explants during establishment stage of few seeded fruit guava trees

Results in Table 2 and Photo 2 show that BA at $2 \mathrm{mg} / 1$ produced the highest number of shoots/ nodal explant (7.83 shoots/explant) accompanied with less significant shoot length $(2.06 \mathrm{~cm})$ and higher number of leaves/ shoot (11.87 leaves/shoot) comparing to lower BA concentrations $(0.5$ and $1 \mathrm{mg} / \mathrm{l})$. On the other side, control treatment recorded the lowest number of shoots/nodal explant and number leaves/shoot (1.20 and 6.20, respectively) and the highest shoot length $(3.45 \mathrm{~cm})$.

\section{Effect of nodal explant inoculation date on some growth parameters during establishment stage of few seeded fruit guava trees}

Results in Table 3 and Photo 3 demonstrate that there was no contamination during spring (mid- April) and summer (mid- July) inoculations, where it reached $52.9 \%$ and $60 \%$ during autumn (mid- October) and winter (midJanuary) inoculations, respectively. Number of shoots/ nodal explant was the highest in spring inoculation (6.18 shoots/nodal explant), followed by summer inoculation (4.33 shoots/ nodal explant), where it was the least in each of autumn and winter inoculation (2.00 shoots/ nodal explant). Average shoot length followed similar trend, while the number of leaves/shoot did not show significant differences in its response to nodal explant inoculation date.

Generally, for the establishment stage, nodal explants are preferred than shoot tips where it gave the highest number of shoots/explant, shoot length, and the highest number of leaves/ shoot. In this regard Amin and Jaiswal (1988) found that culturing nodal explants of guava (Psidium guajava L.) cv. Chittidar on Murashige and Skoog (MS) medium containing $1 \mathrm{mg} / \mathrm{l}$ benzyl adenine, axillary buds grew out within 3-4 weeks. On transfer to fresh medium of the same composition, these shoots attained $3-5 \mathrm{~cm}$ in length and had 4-6 nodes after 4 weeks following culture. Likewise, Mishra et al. (2007) mentioned that culturing nodal segments of guava cv. Pant Prabhatin in MS media containing $4.0 \mathrm{mg} / 1 \mathrm{BA}$ and $0.2 \mathrm{mg} / 1 \mathrm{IBA}$ resulted in higher shoot proliferation.

Concerning effect of BA treatment, $2 \mathrm{mg} / 1$ BA treatment followed by $1 \mathrm{mg} / \mathrm{l}$ was found to be the best concentrations for shoot induction compared with the other tested BA concentrations $(0.0$ and $0.5 \mathrm{mg} / \mathrm{l})$. Likewise, Usman et al. (2012) cleared that shoot induction of guava cv. Safeda was enhanced up to $83 \%$ with 3.5 to 4.25 shoots per single node cutting and shoot tip explants, respectively using higher levels of BAP (1.5 and $2 \mathrm{mg} / \mathrm{l})$ in MS medium. Among inoculation dates, the spring (midApril) was the best time for taking explants, which resulted in the highest parameters followed by the summer season (mid- July). The obtained results are in harmony with Meghwal et al. (2010) worked on micropropagation of guava cv. Allahabad Safeda and found that the nodal explants excised during April-June were better for culture initiation.On the other side, Mohsin et al. (2008) found that when explants of Bari guava were cultured on February, growth parameters such as survival percentage, number of shoots per explant, shoot length, and number of leaves/shoot were higher, followed by March and April. This might be attributed to the varietal differences and different temperatures. 
Table 1. Effect of explant type on some micropropagation parameters during establishment stage of few seeded fruit guava trees

\begin{tabular}{lcccc}
\hline Explant type & $\begin{array}{c}\text { Survival } \\
\text { percentage }\end{array}$ & $\begin{array}{c}\text { Number of shoots / } \\
\text { explant }\end{array}$ & $\begin{array}{c}\text { Shoot length } \\
(\mathbf{c m})\end{array}$ & $\begin{array}{c}\text { Number of } \\
\text { leaves/shoot }\end{array}$ \\
\hline Shoot tips & 100 & $2.67 \mathrm{~b}$ & $1.16 \mathrm{~b}$ & $7.36 \mathrm{~b}$ \\
Nodal explants & 100 & $6.17 \mathrm{a}$ & $2.30 \mathrm{a}$ & $10.09 \mathrm{a}$
\end{tabular}

Means followed by the same letter (s) within each column are not significantly different according to Duncan's multiple range test $(\mathrm{P}=0.05)$

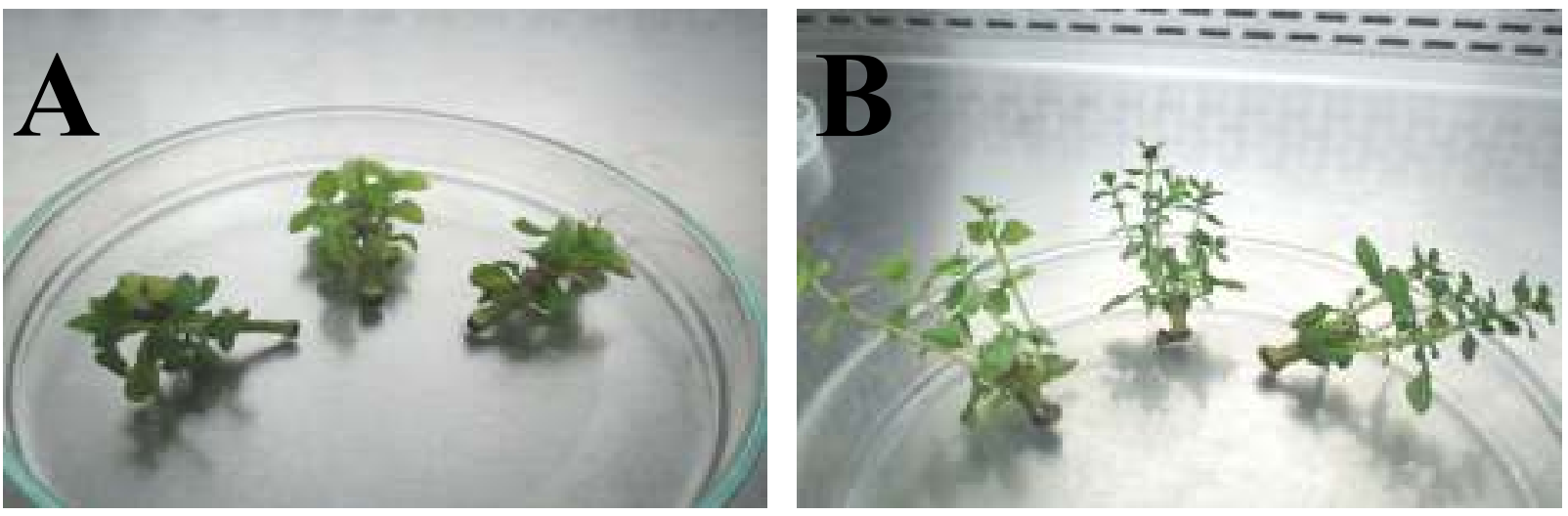

Photo 1. Effect of explant type on some micropropagation parameters during establishment stage of few seeded fruit guava trees
A. Shoot tips
B. Nodal explants.

Table 2. Effect of benzyl adenine (BA) concentration on some growth parameters of nodal explants during establishment stage of few seeded fruit guava trees

\begin{tabular}{lccc}
\hline Treatment & Number of shoots/nodal explant & Shoot length (cm) & Number of leaves/shoot \\
\hline Control & $1.20 \mathrm{~d}$ & $3.45 \mathrm{a}$ & $6.50 \mathrm{~b}$ \\
$\mathbf{0 . 5} \mathbf{~ m g / l ~ B A}$ & $4.00 \mathrm{c}$ & $3.00 \mathrm{ab}$ & $12.15 \mathrm{a}$ \\
$\mathbf{1 . 0} \mathbf{~ m g / l ~ B A}$ & $6.17 \mathrm{~b}$ & $2.30 \mathrm{ab}$ & $10.08 \mathrm{a}$ \\
$\mathbf{2 . 0} \mathbf{~ m g / l ~ B A}$ & $7.83 \mathrm{a}$ & $2.06 \mathrm{~b}$ & $11.87 \mathrm{a}$ \\
\hline
\end{tabular}

Means followed by the same letter (s) within each column are not significantly different according to Duncan's multiple range test $(\mathrm{P}=0.05)$.
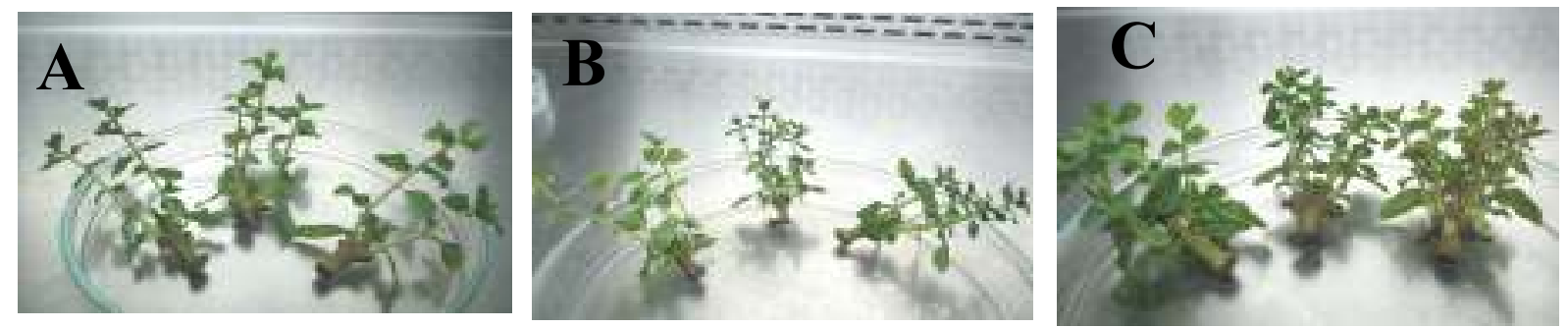

Photo 2. Effect of benzyl adenine (BA) concentration on some growth parameters of nodal explants during establishment stage of few seeded fruit guava trees
A. Control.
B. $1 \mathrm{mg} / 1 \mathrm{BA}$.
C. $2 \mathrm{mg} / \mathrm{l} \mathrm{BA}$. 
Table 3. Effect of nodal explant inoculation date on some growth parameters during establishment stage of few seeded fruit guava trees

\begin{tabular}{lcccc}
\hline Explant inoculation date & $\begin{array}{c}\text { Contamination } \\
\text { percentage }\end{array}$ & $\begin{array}{c}\text { Number of } \\
\text { shoots/explant }\end{array}$ & $\begin{array}{c}\text { Shoot length Number of leaves/ } \\
\text { (cm) }\end{array}$ & \begin{tabular}{c} 
shoot \\
\hline Spring (mid-April)
\end{tabular} \\
Summer (mid- July) & 0.00 & $6.18 \mathrm{a}$ & $2.30 \mathrm{ab}$ & $10.09 \mathrm{a}$ \\
Autumn (mid- October) & 52.90 & $4.33 \mathrm{~b}$ & $2.48 \mathrm{a}$ & $9.18 \mathrm{a}$ \\
Winter (mid- January) & 60.00 & $2.00 \mathrm{c}$ & $1.00 \mathrm{c}$ & $8.40 \mathrm{a}$ \\
& & $2.00 \mathrm{c}$ & $1.80 \mathrm{~b}$ & $9.00 \mathrm{a}$ \\
\hline
\end{tabular}

Means followed by the same letter (s) within each column are not significantly different according to Duncan's multiple range test $(\mathrm{P}=0.05)$.
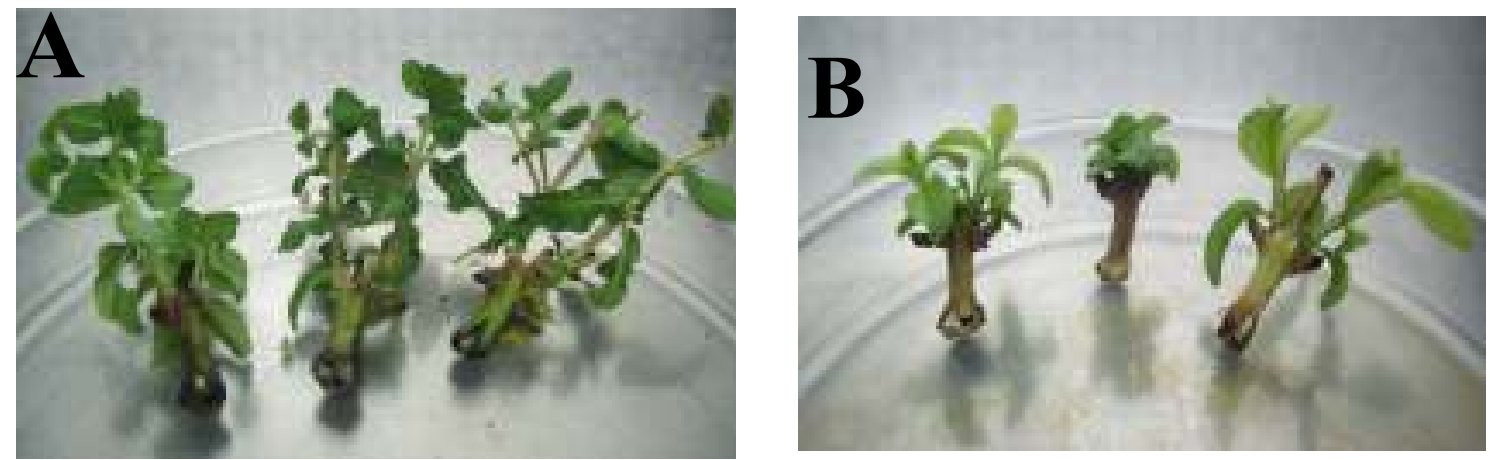

Photo 3. Effect of nodal explant inoculation date on some growth parameters during establishment stage of few seeded fruit guava trees

A. Nodal explants inoculated during summer season. B. Nodal explants inoculated during autumn season.

\section{Multiplication Stage}

Effect of benzyl adenine (BA) concentration on some growth parameters during multiplication stage of few seeded fruit guava trees

Results in Table 4 and Photo 4 illustrate that BA at $2 \mathrm{mg} / 1$ gained the highest number of shoots/ explant (10.62 shoots/explant) accompanied with less significant shoot length $(1.54 \mathrm{~cm})$ and number of leaves/shoot (10.07 leaves/ shoot). The results cleared also that control explants produced $90 \%$ rooting with considerable root length $4.39 \mathrm{~cm}$, that was not obtained for BA concentrations since it depressed rooting process.

Effect of kinetin (Kin.) concentration on some growth parameters during multiplication stage of few seeded fruit guava trees

Table 5 reveal that kinetin was not promising in enhancing number of shoots / explant and significantly depressed shoot length without any significant effect on number of leaves/shoot. On the other side, rooting percentage was decreased as kinetin concentration increased, while number of roots and root length were decreased with all kinetin concentrations comparing to control. The highest values for those parameters were belong to control.

Effect of sucrose concentration in MS medium supplemented with $2 \mathrm{mg} / \mathrm{l}$ BA on multiplication stage of few seeded fruit guava trees

Results in Table 6 and Photo 5 show that increasing sucrose concentration up to $40 \mathrm{mg} / 1$ resulted in more significant shoots number/ explant than 20 or $30 \mathrm{mg} / 1$ sucrose. However, both shoot length and number of leaves/shoot were not significantly affected with sucrose concentration. 
Zagazig J. Agric. Res., Vol. 44 No. (3) 2017

Table 4. Effect of benzyl adenine (BA) concentration on some growth parameters during multiplication stage of few seeded fruit guava trees

\begin{tabular}{lcccccc}
\hline Treatment & $\begin{array}{c}\text { Number of } \\
\text { shoots/explant }\end{array}$ & $\begin{array}{c}\text { Shoot length } \\
\text { (cm) }\end{array}$ & $\begin{array}{c}\text { Number of } \\
\text { leaves/shoot }\end{array}$ & $\begin{array}{c}\text { Rooting } \\
\text { percentage }\end{array}$ & $\begin{array}{c}\text { Number of } \\
\text { roots/shoot }\end{array}$ & $\begin{array}{c}\text { Root length } \\
\text { (cm) }\end{array}$ \\
\hline Control & $1.80 \mathrm{~d}$ & $3.10 \mathrm{a}$ & $12.07 \mathrm{a}$ & 90.00 & $2.80 \mathrm{a}$ & $4.39 \mathrm{a}$ \\
$\mathbf{0 . 5} \mathbf{~ m g / l ~ B A ~}$ & $3.22 \mathrm{c}$ & $2.18 \mathrm{~b}$ & $9.99 \mathrm{~b}$ & 10.00 & $0.30 \mathrm{~b}$ & $0.10 \mathrm{~b}$ \\
$\mathbf{1 . 0} \mathbf{~ m g / l ~ B A}$ & $5.88 \mathrm{bc}$ & $1.84 \mathrm{bc}$ & $9.96 \mathrm{~b}$ & 0.00 & $0.00 \mathrm{~b}$ & $0.00 \mathrm{~b}$ \\
$\mathbf{2 . 0} \mathbf{~ m g / l ~ B A}$ & $10.62 \mathrm{a}$ & $1.54 \mathrm{c}$ & $10.07 \mathrm{~b}$ & 0.00 & $0.00 \mathrm{~b}$ & $0.00 \mathrm{~b}$ \\
$\mathbf{4 . 0} \mathbf{~ m g / l ~ B A ~}$ & $8.66 \mathrm{ab}$ & $1.88 \mathrm{bc}$ & $10.33 \mathrm{~b}$ & 0.00 & $0.00 \mathrm{~b}$ & $0.00 \mathrm{~b}$ \\
$\mathbf{6 . 0} \mathbf{~ m g / l ~ B A}$ & $6.90 \mathrm{~b}$ & $1.94 \mathrm{bc}$ & $11.25 \mathrm{ab}$ & 0.00 & $0.00 \mathrm{~b}$ & $0.00 \mathrm{~b}$ \\
\hline
\end{tabular}

Means followed by the same letter (s) within each column are not significantly different according to Duncan's multiple range test $(\mathrm{P}=0.05)$.
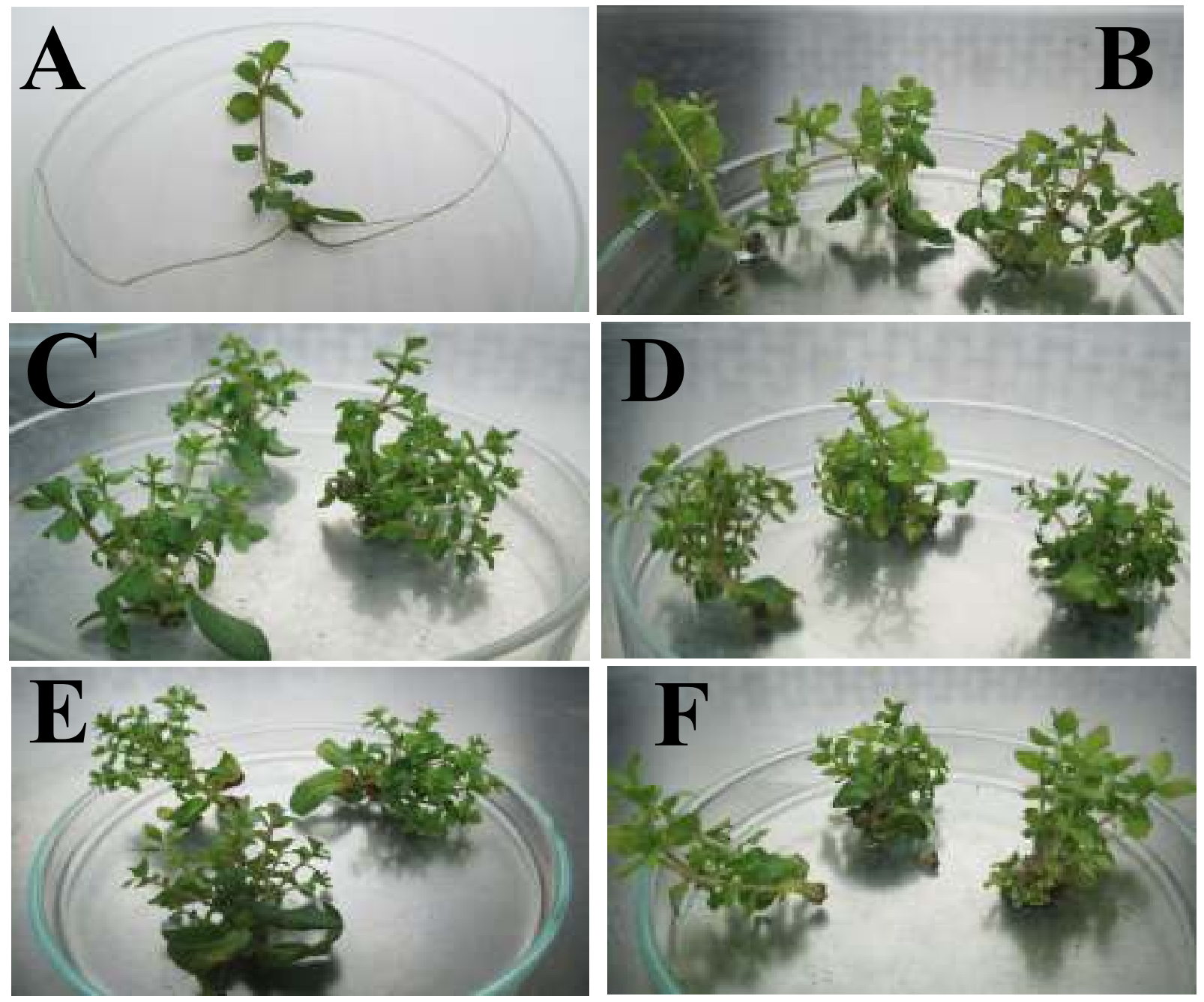

Photo 4. Effect of benzyl adenine (BA) concentration on some growth parameters during multiplication stage of few seeded fruit guava trees
A. Control.
D. $2 \mathrm{mg} / \mathrm{l} \mathrm{BA}$.
B. $0.5 \mathrm{mg} / 1 \mathrm{BA}$.
E. $4 \mathrm{mg} / \mathrm{l} \mathrm{BA}$.
C. $1 \mathrm{mg} / 1 \mathrm{BA}$.
F. $6 \mathrm{mg} / \mathrm{l} \mathrm{BA}$. 
Table 5. Effect of kinetin (Kin.) concentration on some growth parameters during multiplication stage of few seeded fruit guava trees

\begin{tabular}{lcccccc}
\hline Treatment & $\begin{array}{c}\text { Number of } \\
\text { shoots/explant }\end{array}$ & $\begin{array}{c}\text { Shoot } \\
\text { length }(\mathbf{c m})\end{array}$ & $\begin{array}{c}\text { Number of } \\
\text { leaves/shoot }\end{array}$ & $\begin{array}{c}\text { Rooting } \\
\text { percentage }\end{array}$ & $\begin{array}{c}\text { Number of } \\
\text { roots/shoot }(\mathbf{c m})\end{array}$ & $\begin{array}{c}\text { Root } \\
\text { length } \mathbf{( c m})\end{array}$ \\
\hline Control & $1.20 \mathrm{ab}$ & $3.58 \mathrm{a}$ & $13.20 \mathrm{a}$ & 90.00 & $1.60 \mathrm{a}$ & $4.72 \mathrm{a}$ \\
$\mathbf{0 . 5} \mathbf{~ m g / l ~ K i n . ~}$ & $1.40 \mathrm{a}$ & $2.01 \mathrm{~b}$ & $11.50 \mathrm{a}$ & 40.00 & $1.00 \mathrm{~b}$ & $0.40 \mathrm{~b}$ \\
$\mathbf{1 . 0} \mathbf{~ m g / l ~ K i n . ~}$ & $1.10 \mathrm{ab}$ & $2.50 \mathrm{~b}$ & $11.30 \mathrm{a}$ & 30.00 & $1.02 \mathrm{~b}$ & $0.90 \mathrm{~b}$ \\
$\mathbf{2 . 0} \mathbf{~ m g / l ~ K i n . ~}$ & $1.00 \mathrm{~b}$ & $2.25 \mathrm{~b}$ & $11.50 \mathrm{a}$ & 20.00 & $0.60 \mathrm{~b}$ & $0.13 \mathrm{~b}$ \\
$\mathbf{4 . 0} \mathbf{~ m g / l ~ K i n . ~}$ & $1.00 \mathrm{~b}$ & $2.27 \mathrm{~b}$ & $11.20 \mathrm{a}$ & 10.00 & $0.20 \mathrm{~b}$ & $0.10 \mathrm{~b}$ \\
$\mathbf{6 . 0} \mathbf{~ m g / l ~ K i n . ~}$ & $1.00 \mathrm{~b}$ & $2.01 \mathrm{~b}$ & $11.10 \mathrm{a}$ & 10.00 & $0.30 \mathrm{~b}$ & $0.13 \mathrm{~b}$ \\
\hline
\end{tabular}

Means followed by the same letter (s) within each column are not significantly different according to Duncan's multiple range test $(\mathrm{P}=0.05)$.

Table 6. Effect of sucrose concentration in MS medium supplemented with $2 \mathrm{mg} / \mathrm{l}$ BA on multiplication stage of few seeded fruit guava trees

\begin{tabular}{lccc}
\hline Sucrose concentration (g/l) & $\begin{array}{c}\text { Average number of } \\
\text { shoots/ explant }\end{array}$ & $\begin{array}{c}\text { Average shoot } \\
\text { length(cm) }\end{array}$ & $\begin{array}{c}\text { Average number } \\
\text { of leaves/shoot }\end{array}$ \\
\hline $\mathbf{2 0}$ & $6.00 \mathrm{~b}$ & $0.90 \mathrm{a}$ & $9.89 \mathrm{a}$ \\
$\mathbf{3 0}$ (control) & $7.27 \mathrm{~b}$ & $0.90 \mathrm{a}$ & $9.65 \mathrm{a}$ \\
$\mathbf{4 0}$ & $12.00 \mathrm{a}$ & $0.85 \mathrm{a}$ & $8.40 \mathrm{a}$ \\
\hline
\end{tabular}

Means followed by the same letter (s) within each column are not significantly different according to Duncan's multiple range test $(\mathrm{P}=0.05)$.

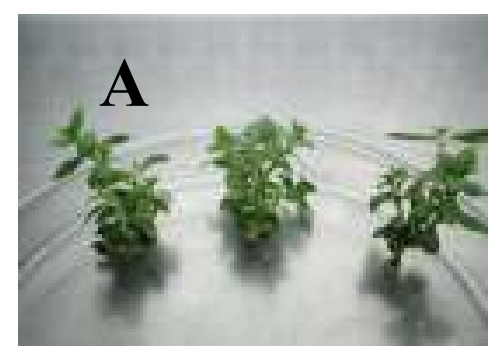

(6.00 shoots/explant)

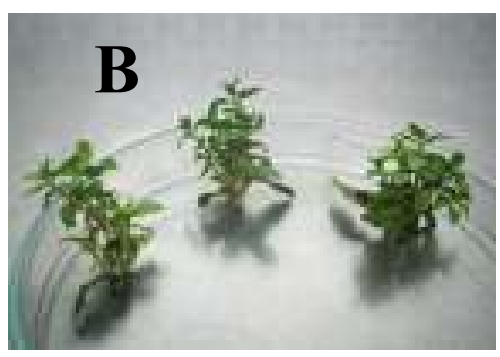

(7.27 shoots/explant)

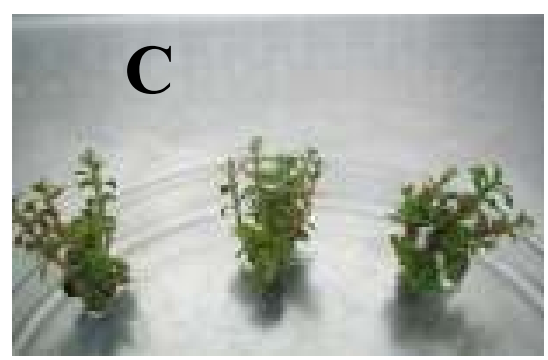

(12.00 shoots/explant)

Photo 5. Effect of sucrose concentration in MS medium supplemented with $2 \mathrm{mg} / \mathrm{l}$ BA on multiplication stage of few seeded fruit guava trees
A. $20 \mathrm{~g} / 1$ sucrose.
B. $30 \mathrm{~g} / 1$ sucrose.
C. $40 \mathrm{~g} / 1$ sucrose. 
Effect of 2mg/l BA combined with different auxins concentrations on multiplication stage of few seeded fruit guava trees

Results in Table 7 and Photo 6 demonestrat that addition of 0.5 or $1 \mathrm{mg} / 1 \mathrm{NAA}$ or IAA and $1 \mathrm{mg} / \mathrm{l} \mathrm{IBA}$ suppressed the enhancing effect of $2 \mathrm{mg} / \mathrm{l} \mathrm{BA}$ on number of shoots/explant. On the contrary, when $0.5 \mathrm{mg} / \mathrm{l} \mathrm{IBA}$ was combined with $2 \mathrm{mg} / \mathrm{l} \mathrm{BA}$ resulted in significant increase in number of shoots/explant than using $2 \mathrm{mg} / \mathrm{l} \mathrm{BA}$ alone. However, application of IAA or IBA combined with $2 \mathrm{mg} / \mathrm{l}$ BA significantly enhanced shoot length, while the maximum number of leaves/ shoot was obtained when $2 \mathrm{mg} / \mathrm{l} \mathrm{BA}$ combined with $1 \mathrm{mg} / 1 \mathrm{IAA}$ or NAA without significant differences between them.

Generally, the highest multiplication rate (number of shoots/explant) was obtained by 2 $\mathrm{mg} / \mathrm{l} \mathrm{BA}$. Increasing BA concentration up to 6 $\mathrm{mg} / \mathrm{l}$ decreased number of shoots /explant. This indicate that BA had an adverse effect when used at a higher than moderate concentration. On the other hand, using Kin. alone at 0.0, 0.5,1, 2,4 or $6 \mathrm{mg} / \mathrm{l}$ was not effective in shoot multiplication compared with BA, and did not differ significantly than control treatment (produced approximately only one shoot/ explant). The aforementioned findings are in harmony with Rai et al. (2009) worked on micropropagation of guava and mentioned that BAP was more effective than Kin in inducing shoot proliferation. On medium containing Kin; only one shoot was developed per an explant or there was no shoot proliferation at all. Likewise, Strosse et al. (2008) found that the cytokinins thidiazuron and benzyl aminopurine stimulated multiplication of banana to a larger extent compared to zeatin, kinetin and isopentenyl adenine.

Also, shoot proliferation of lemon decreased with increasing concentration of BA alone, (Goswami et al., 2013). Superiority of BA for shoot induction may be attributed to the ability of plant tissues to metabolize BA more readily than other synthetic growth regulators (Malik et al., 2005).
Application of sucrose at 20,30 or $40 \mathrm{~g} / 1$ to MS medium provided with $2 \mathrm{mg} / 1$ BA declared that $40 \mathrm{~g} / 1$ sucrose gave the highest number of shoots/explant, but produced the shortest shoots and the least number of leaves/ shoot compared with 20 or $30 \mathrm{~g} / 1$ sucrose. In this regard, Usman et al. (2012) worked on micropropagation of Elite guava (Psidium guajava L.) strains of $\mathrm{cv}$. Safeda, found that enhancing sucrose supplement to $45 \mathrm{~g} / 1$ improved plant growth and development of shoot and root length as well as leaf area compared to $30 \mathrm{~g} / \mathrm{l}$ of sucrose in the media.

Using $2 \mathrm{mg} / 1 \mathrm{BA}$ alone or combined with low concentrations ( 0.50 or $1 \mathrm{mg} / \mathrm{l}$ ) of different auxins (NAA, IAA, or IBA) cleared that $2 \mathrm{mg} / 1$ BA combined with $0.5 \mathrm{mg} / \mathrm{l}$ IBA gave the highest multiplication rate and the longest shoots compared with $2 \mathrm{mg} / \mathrm{l} \mathrm{BA}$ alone without significant difference between them in number of leaves /shoot. The obtained result was in harmony with Mishra et al. (2007) who revealed that higher shoot growth of guava cv. Pant Prabhat was recorded with $3.0 \mathrm{mg} / \mathrm{l} \mathrm{BA}$ and 0.2 mg/l IBA. Likewise, Rabeh et al. (2015) performed a study on micropropagation of guava cvs. Banaty, Sabahy and Mobaker, and mentioned that BA at $1.0 \mathrm{mg} / 1$ gained the best effect on shoot production per explant of the three guava cultivars, but the better effects on shoot production were obtained when IBA at 0.02 to $2.0 \mathrm{mg} / 1$ combined with $\mathrm{BA}$ at $1-2 \mathrm{mg} / 1$ were used.

\section{Rooting Stage}

Effect of different auxins on some growth parameters during rooting stage of few seeded fruit guava trees.

Table 8 and Photo 7 indicate that with control treatment (without auxin addition) rooting percentage was $80 \%$, while it increased to be $100 \%$ with all auxins concentrations. NAA concentrations significantly depressed root length while IBA concentrations (2and $4 \mathrm{mg} / \mathrm{l}$ ) and $0.5 \mathrm{mg} / 1 \mathrm{IAA}$ significantly enhanced it and came in the maximum length $(4.50,5.30$ and 
Mahmoud, et al.

Table 7. Effect of $2 \mathrm{mg} / \mathrm{l}$ BA combined with different auxins concentrations on some growth parameters during multiplication stage of few seeded fruit guava trees

\begin{tabular}{lccc}
\hline Auxin concentration (mg/l) & $\begin{array}{c}\text { Number of } \\
\text { shoots/explant }\end{array}$ & $\begin{array}{c}\text { Shoot length } \\
(\mathbf{c m})\end{array}$ & $\begin{array}{c}\text { Number of } \\
\text { leaves/shoot }\end{array}$ \\
\hline 2BA alone & $7.26 \mathrm{~b}$ & $1.17 \mathrm{c}$ & $10.07 \mathrm{bc}$ \\
2BA+ 0.5 NAA & $2.56 \mathrm{c}$ & $0.94 \mathrm{~d}$ & $9.89 \mathrm{bc}$ \\
2BA+ 1 NAA & $1.33 \mathrm{c}$ & $1.19 \mathrm{bc}$ & $11.26 \mathrm{ab}$ \\
2BA+ 0.5 IAA & $8.00 \mathrm{~b}$ & $1.14 \mathrm{c}$ & $9.14 \mathrm{c}$ \\
2BA+ 1 IAA & $7.66 \mathrm{~b}$ & $1.38 \mathrm{ab}$ & $12.54 \mathrm{a}$ \\
2BA+ 0.5 IBA & $11.22 \mathrm{a}$ & $1.51 \mathrm{a}$ & $10.87 \mathrm{~b}$ \\
2BA+ 1 IBA & $7.83 \mathrm{~b}$ & $1.49 \mathrm{a}$ & $10.57 \mathrm{bc}$
\end{tabular}

Means followed by the same letter(s) within each column are not significantly different according to Duncan's multiple range test $(\mathrm{P}=0.05)$.
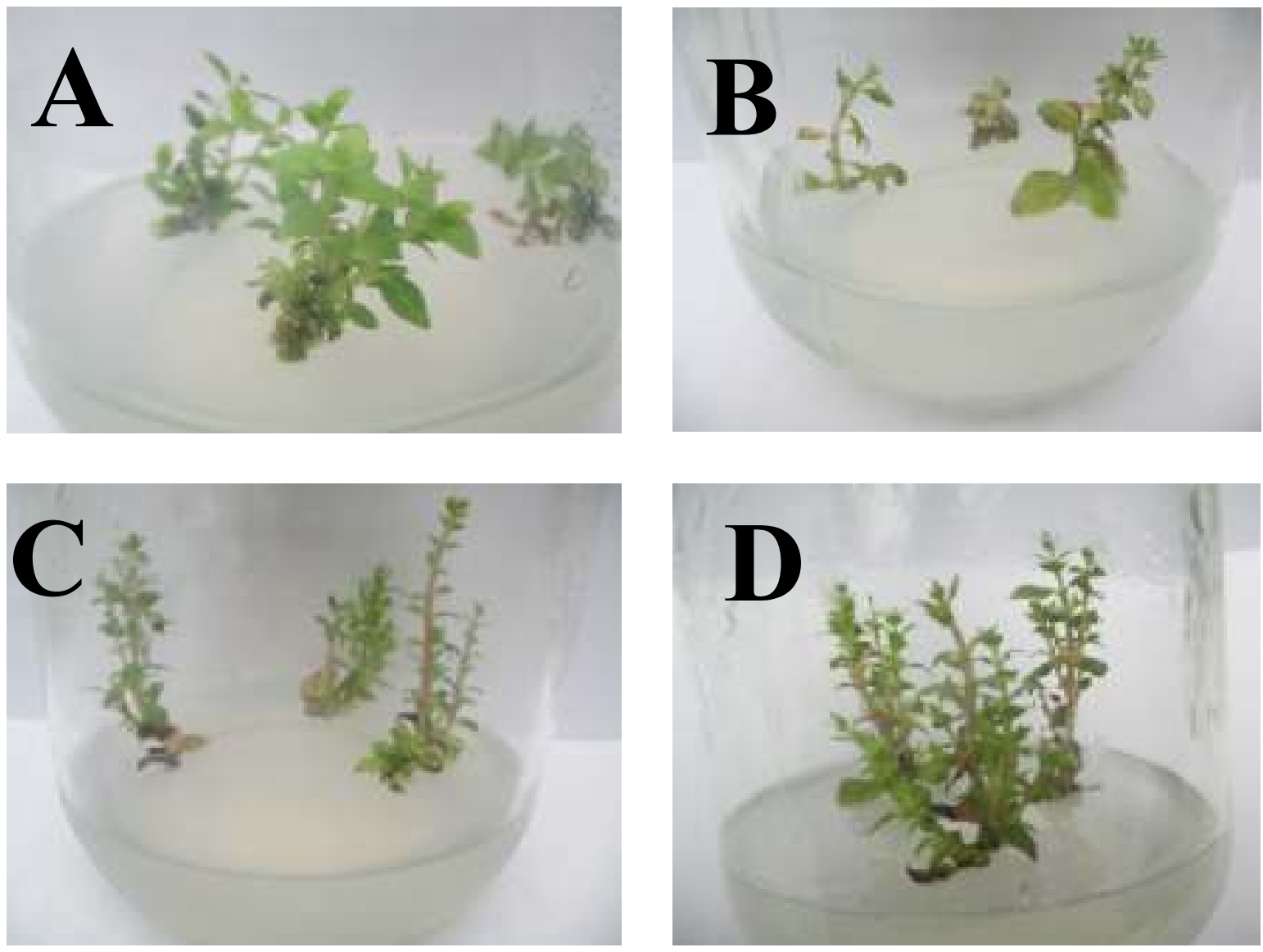

Photo 6. Effect of $2 \mathrm{mg} / \mathrm{l}$ BA combined with different auxins concentrations on some growth parameters during multiplication stage of few seeded fruit guava trees
A. $2 \mathrm{mg} / 1 \mathrm{BA}$ alone.
B. $2 \mathrm{mg} / 1 \mathrm{BA}+0.5 \mathrm{mg} / \mathrm{l} \mathrm{NAA}$.
C. $2 \mathrm{mg} / 1 \mathrm{BA}+1 \mathrm{mg} / \mathrm{l} \mathrm{IAA}$.
D. $2 \mathrm{mg} / \mathrm{l} \mathrm{BA}+0.5 \mathrm{mg} / \mathrm{l} \mathrm{IBA}$. 
Zagazig J. Agric. Res., Vol. 44 No. (3) 2017

Table 8. Effect of different auxins on some growth parameters during rooting stage of few seeded fruit guava trees

\begin{tabular}{lccccc}
\hline Auxins concentrations (mg/l) & $\begin{array}{c}\text { Rooting } \\
(\%)\end{array}$ & $\begin{array}{c}\text { Number of } \\
\text { roots/shoot }\end{array}$ & $\begin{array}{c}\text { Root length } \\
(\mathbf{c m})\end{array}$ & $\begin{array}{c}\text { Shoot length } \\
(\mathbf{c m})\end{array}$ & $\begin{array}{c}\text { Number of } \\
\text { leaves/shoot }\end{array}$ \\
\hline Control & $80.00 \mathrm{~b}$ & $1.40 \mathrm{~d}$ & $2.66 \mathrm{c}$ & $2.99 \mathrm{c}$ & $14.63 \mathrm{~b}$ \\
0.5 NAA & $100.00 \mathrm{a}$ & $6.68 \mathrm{c}$ & $1.19 \mathrm{~d}$ & $1.85 \mathrm{~cd}$ & $11.78 \mathrm{~cd}$ \\
1 NAA & $100.00 \mathrm{a}$ & $9.29 \mathrm{~b}$ & $0.97 \mathrm{~d}$ & $2.33 \mathrm{c}$ & $13.11 \mathrm{c}$ \\
2 NAA & $100.00 \mathrm{a}$ & $14.50 \mathrm{a}$ & $0.78 \mathrm{~d}$ & $1.30 \mathrm{~d}$ & $9.60 \mathrm{de}$ \\
4 NAA & $100.00 \mathrm{a}$ & $13.18 \mathrm{ab}$ & $0.45 \mathrm{~d}$ & $1.35 \mathrm{~d}$ & $9.00 \mathrm{de}$ \\
0.5 IAA & $100.00 \mathrm{a}$ & $1.90 \mathrm{~d}$ & $4.79 \mathrm{ab}$ & $4.11 \mathrm{ab}$ & $11.50 \mathrm{~cd}$ \\
1 IAA & $100.00 \mathrm{a}$ & $2.30 \mathrm{~d}$ & $3.37 \mathrm{bc}$ & $4.45 \mathrm{ab}$ & $17.20 \mathrm{a}$ \\
2 IAA & $100.00 \mathrm{a}$ & $2.36 \mathrm{~d}$ & $3.42 \mathrm{bc}$ & $4.02 \mathrm{ab}$ & $15.50 \mathrm{ab}$ \\
4 IAA & $100.00 \mathrm{a}$ & $2.44 \mathrm{~d}$ & $1.17 \mathrm{~d}$ & $4.58 \mathrm{a}$ & $16.29 \mathrm{a}$ \\
0.5 IBA & $100.00 \mathrm{a}$ & $1.60 \mathrm{~d}$ & $1.43 \mathrm{~d}$ & $2.03 \mathrm{~cd}$ & $12.83 \mathrm{c}$ \\
1 IBA & $100.00 \mathrm{a}$ & $2.60 \mathrm{~d}$ & $4.17 \mathrm{~b}$ & $3.79 \mathrm{~b}$ & $12.26 \mathrm{c}$ \\
2 IBA & $100.00 \mathrm{a}$ & $2.14 \mathrm{~d}$ & $4.50 \mathrm{ab}$ & $2.29 \mathrm{c}$ & $10.58 \mathrm{~d}$ \\
4 IBA & $100.00 \mathrm{a}$ & $2.00 \mathrm{~d}$ & $5.30 \mathrm{a}$ & $1.56 \mathrm{~cd}$ & $8.40 \mathrm{e}$ \\
\hline
\end{tabular}

Means followed by the same letter(s) within each column are not significantly different according to Duncan's multiple range test $(\mathrm{P}=0.05)$.
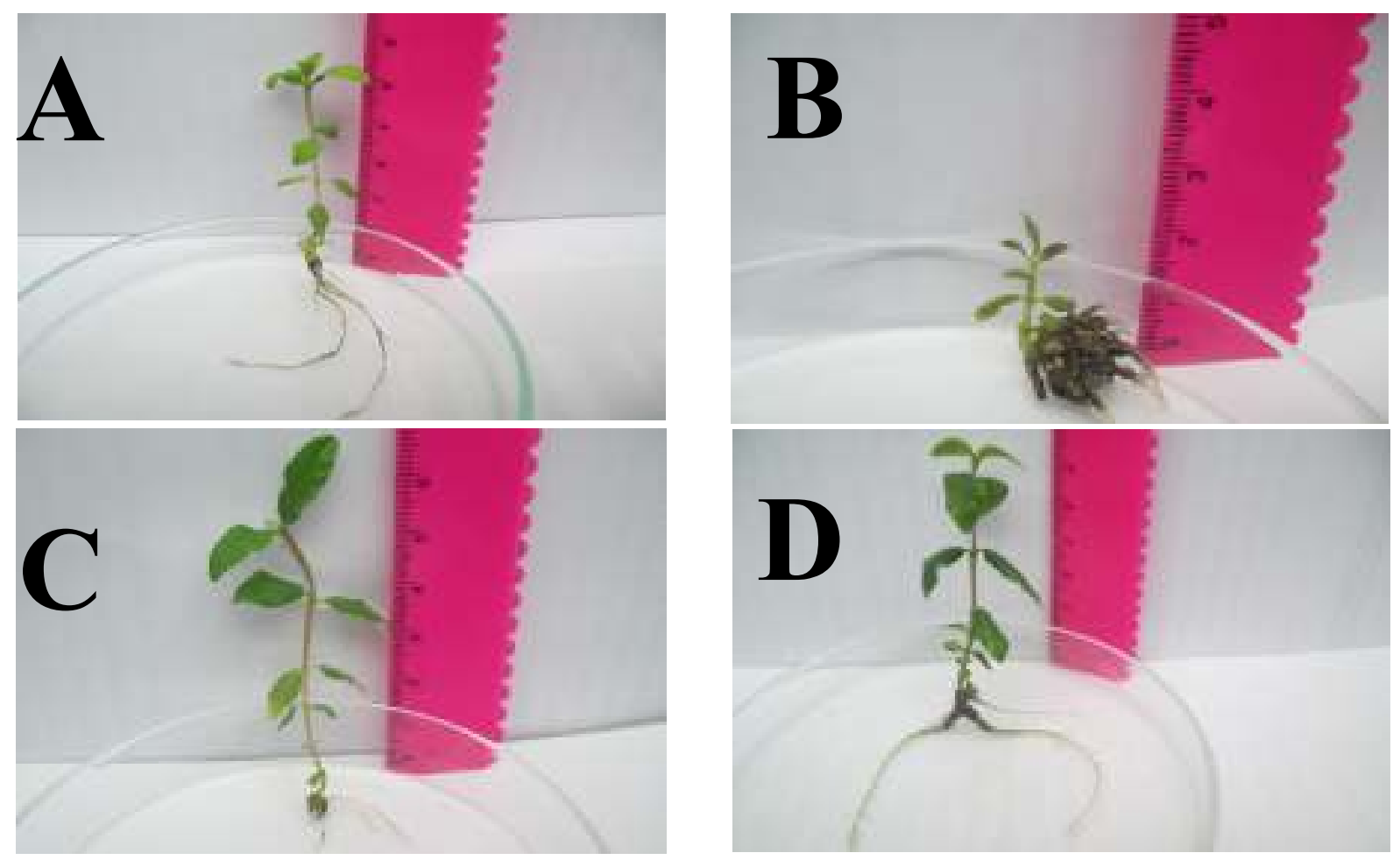

Photo 7. Effect of different auxins on some growth parameters during rooting stage of few seeded fruit guava trees
A. The control.
B. $2 \mathrm{mg} / 1 \mathrm{NAA}$.
C. $4 \mathrm{mg} / 1$ IAA.
D. $2 \mathrm{mg} / \mathrm{l} \mathrm{IBA}$. 
$4.79 \mathrm{~cm}$, respectively). Shoot length recorded the highest values with $0.5,1,2$, or $4 \mathrm{mg} / 1 \mathrm{IAA}$, while it recorded the least significant values with 2 or $4 \mathrm{mg} / \mathrm{l}$ NAA. Also, number of leaves/ shoot followed a similar trend to that of shoot length parameters.

In the herein work, NAA was more effective in enhancing number of roots / shoot, especially at 2 and $4 \mathrm{mg} / \mathrm{l}$, while IBA at 1, 2, or $4 \mathrm{mg} / \mathrm{l}$ was more effective in enhancing root length during rooting stage . Likewise, IAA at $0.5,1$, or $2 \mathrm{mg} / 1$ was the most effective in enhancing shoot length and number of leaves/shoot during rooting stage. However, it was clear that IBA at 1 or $2 \mathrm{mg} / 1$ was adequate during rooting stage to produce good rooting shoots for the following acclimatization stage. In this regard, Pierik (1987) pointed out that the most efficient auxins were definitely IBA and NAA. Also, Gokhale and Bansal (2009) mentioned that although all the 3 auxins (NAA, IAA, and IBA) induced rooting in vitro propagation of Orxylum indicum (L.) Vent, yet IBA responced better for all parameters of rooting. IBA is a potential auxin that induces rooting in vitro regenerated shoots
(Iriondo et al., 1995 ; Rajore and Batra, 2005). Similarly, Baskaran and Jayabalan (2005) on Eclipta alba mentioned that full strength MS medium fortified with $9.8 \mu \mathrm{M}$ IBA showed better root formation compared to half strength MS medium with $9.8 \mu \mathrm{M}$ IBA. Moreover, it promoted lengthy roots and strengthened root induction within twenty days of culture. This was true for Full MS strength for date palm explants (Badawy et al., 2005).

\section{Acclimatization Stage}

\section{Effect of media on plantlets growth after 6 weeks later of acclimatization stage}

Results in Table 9 show that the best adapting medium was 2 sand: 1 peat moss $(V / V)$ which gave $100 \%$ survival percentage, long plantlets $(6.08 \mathrm{~cm})$, and high number of leaves/ plantlet (13. 39 leaves/ plantlet), descendungly followed by 1 sand : 1 peat moss $(V / V)$ with values (96.88\%, 6.39 and 14.14, respectively). Peat moss alone gained similar survival percentage to that of 1sand: 1 Peat moss medium $(96.88 \%)$, but it recorded the least plantlet length and number of leaves/ plantlet.

Table 9. Effect of acclimatization media on plantlets growth parameters after 6 weeks later of acclimatization stage

\begin{tabular}{lccc}
\hline Acclimatization media $(\boldsymbol{V} / \boldsymbol{V})$ & $\begin{array}{c}\text { Survival } \\
\text { percentage }\end{array}$ & $\begin{array}{c}\text { Plantlet length } \\
(\mathbf{c m})\end{array}$ & $\begin{array}{c}\text { Number of leaves/ } \\
\text { plantlet }\end{array}$ \\
\hline 1 sand : 1 peat moss & 96.88 & $6.39 \mathrm{a}$ & $14.14 \mathrm{a}$ \\
$\mathbf{2}$ sand : 1 peat moss & 100.00 & $6.08 \mathrm{a}$ & $13.39 \mathrm{ab}$ \\
3 sand : 1 peat moss & 90.91 & $5.65 \mathrm{ab}$ & $12.02 \mathrm{~b}$ \\
Peat moss alone & 96.88 & $4.99 \mathrm{~b}$ & $12.18 \mathrm{~b}$
\end{tabular}

Means followed by the same letter(s) within each column are not significantly differ according to Duncan's multiple range test $(\mathrm{P}=0.05)$. 


\section{REFERENCES}

Amin, M.N. and V.S. Jaiswal (1988). Micropropagation as an aid to rapid cloning of a guava cultivar. Scientia Hort., 36 (1-2) : 89-95.

Badawy, E.M., A.M.A. Habib, A. El-Bana and G.M. Yosry (2005). Propagation of date palm (Phoenix dactylifera) plants by using tissue culture technique. Arab J. Biotech., 8 (2): 343- 354.

Baskaran, P. and N. Jayabalan (2005). Role of basal media, carbon sources, and growth regulators in micropropagation of Eclipta alba -a valuable medicinal herb. Kmitl Sci. J., 5 (2).

Duncan, B.D. (1955). Multiple Range and Multiple F tests. Biometric, II: 1-42.

Gokhale, M. and Y.K. Bansal (2009). Direct in vitro regeneration of a medicinal tree Oroxylum indicum (L.) Vent. through tissue culture. Afr. J. Biotechnol., 8 (16): 37773781 .

Goswami, K., R. Sharma, P.K. Singh and S. Govind (2013). Micropropagation of seedless lemon (Citrus limon L. cv. Kaghzi Kalan) and assessment of genetic fidelity of micropropagated plants using RAPD markers. Physiol. and Molecular Biol. Pl., 19 (1): 137-145.

Iriondo, J.M., C. Moreno and C. Perez (1995). Micropropagation of six Rootstock (citrus) species. Hort. Sci., 30 (5): 1080-1081.

Malik, S.K., R. Chaudhury and R.K. Kalia (2005). Rapid in vitro multiplication and conservation of Garcinia indica: A tropical medicinal tree species. Sci. Hort., 106 : 539553.

Meghwal, P.R., H.C. Sharma and S.K. Singh (2010). Micropropagation studies on guava. Indian J. Hort., 67 : 55-58.
Mishra, D.S., J.P. Tiwari and S.H. Lal (2007). In vitro cloning of guava (Psidium guajava $\mathrm{L}$.) cv. Pant Prabhat. Acta Hort., 735:127-132.

Mohsin, M.G., M.A. Haque, A.J. Kakon and R. Karim (2008). Effect of month of collection on survivability and growth of guava explants on a tissue culture medium. SAARC J. Agric., 6 (2): 49-58.

Murashige, T. and F. Skoog (1962). A revised medium for rapid growth and bioassays with tobacco tissue culture. Physiol. Plant, 15: 473-497.

Pierik, R.L.M. (1987). In vitro Culture of Higher Plants. Martinus Nijhoff Publishers, Dordrecht, Netherlands.

Rabeh, R.M., S.A. Ahmed, A.A. Kasem and B.S. Salama (2015). In vitro culture of some guava cultivars, surface-sterilization and proliferation stage. Minufiya J. Agric. Res., 40 (1) : 131-138.

Rai, M.K., V.S. Jaiswal and U. Jaiswal (2009). Shoot multiplication and plant regeneration of guava (Psidium guajava L.) from nodal explants of in vitro raised plantlets. J. Fruit and Ornam. Plant Res., 17 (1): 29-38.

Rajore, S. and A. Batra (2005). Efficient plant regeneration via shoot tip explant in Jatropha curcas L. J. Plant Biochem. Biotech., 14 : 73- 75.

Snedecor, G.W. and W.G. Cochran (1980). Statistical Methods. $7^{\text {th }}$ Ed. Iowa State Univ. Press. Ames, Iowa, USA.

Strosse, H., E. Andre, L. Sági, R. Swennen and B. Panis (2008). Adventitious shoot formation is not inherent to micropropagation of banana as it is in maize.Plant Cell, Tissue and Organ Culture, 95:321.

Usman, M., M. Butt and F. Bilquees (2012). Enhanced in vitro multiple shoot induction in elite Pakistani guava cultivars for efficient clonal plant multiplication. Afr. J. Biotechnol., 11 (44):10182-10187. 
تقييم بعض العوامل المؤثرة على الإكثار الاقيق بزراعة الأنسجة لأثجار الجوافة ذات الثمار قليلة البذور

\author{
دعاء صبرى محمود - جميل فهيم سوريال- عطيات سيد عبد العزيز- رزق عبد الحميد الأثقر \\ قسم البساتين - كلية الزراعة - جامعة الزقازيقـ مصرد
}

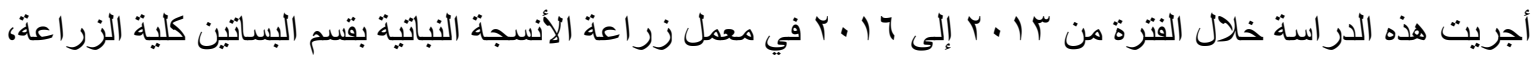

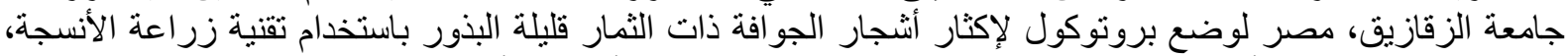

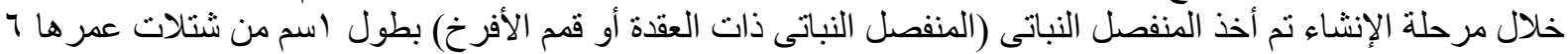

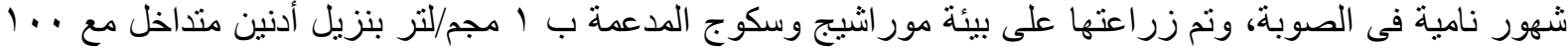

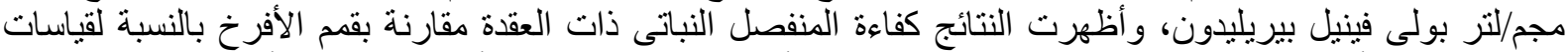

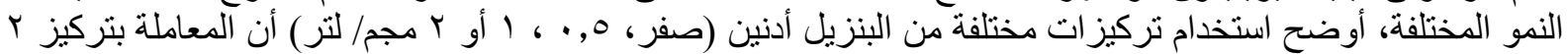

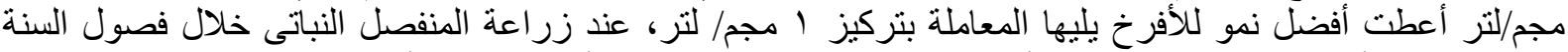

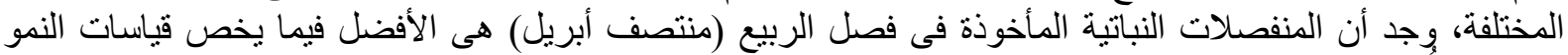

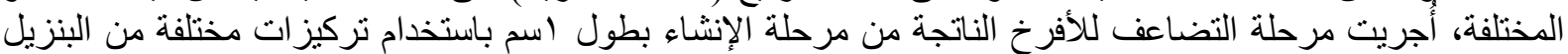

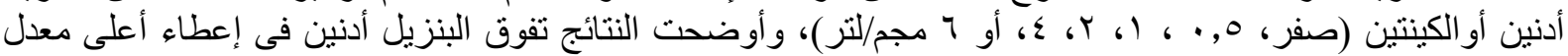

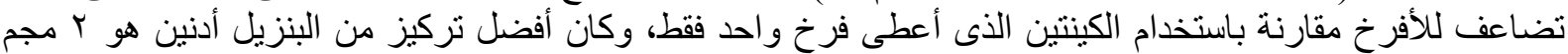

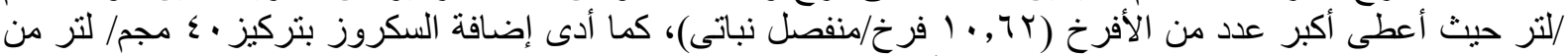

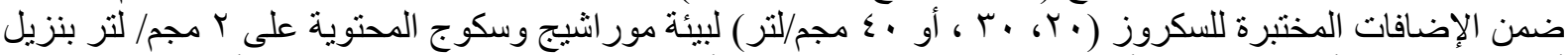

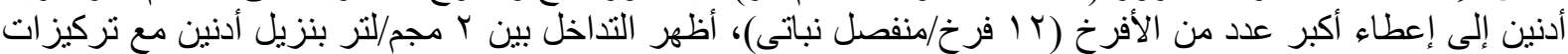

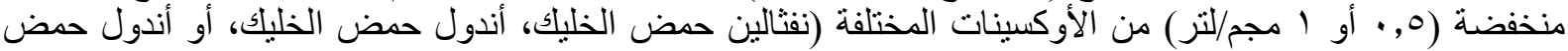

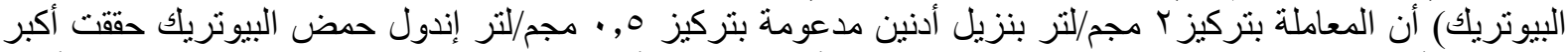

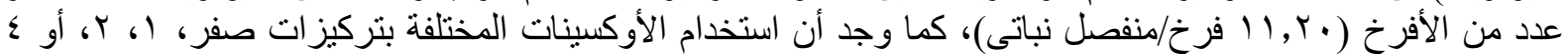

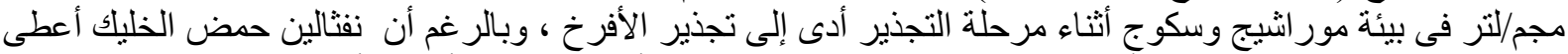

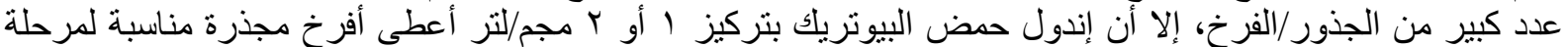

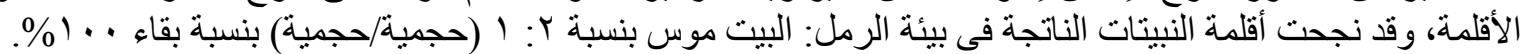

